\title{
A QUANTITATIVE ASSESSMENT OF AN INNOVATIVE EDUCATION PROJECT FOR PHARMACY STUDENTS
}

\author{
Zuzana Pagáčová, ${ }^{1}$ Daniela Mináriková ${ }^{2}$
}

\begin{abstract}
The changing environment of pharmacy care represents an opportunity to implement an innovative educational form into the teaching process, which represents a significant potential in preparing pharmacy students for their future profession. The main objective of the assessment was to evaluate the contribution of the innovative education project Advanced Training in Pharmacy Care (ATIP) as a complement to the compulsory curriculum at the Faculty of Pharmacy of the Comenius University in Bratislava. Another objective was to analyse the obstacles to dispensation and counselling perceived by students of the educational project. The assessment uses data from the ATIP educational project carried out between 2015/2016 and 2020/2021 at the Faculty of Pharmacy of the Comenius University in Bratislava. Data collection was provided through a questionnaire survey among the participating students after completing each year of the project. The assessment focused on students' perception of the ATIP educational project, characterizing their readiness to provide pharmacy care and obstacles to the implementation of pharmacy care. Students perceived the project as an interesting addition to the curriculum, which was organized at a high professional level with reasonable difficulty. In the case of their readiness for their future profession by studying and passing compulsory practice, students were critical in their answers. Obstacles affecting the implementation of pharmacy care that prevailed among students were a lack of practical experience, a lack of time to address the patients' problems, and different requirements of patients from the knowledge acquired during study at the faculty. In other obstacles, such as a patient's lack of interest, lack of privacy to talk, etc., students have taken a neutral stance. This innovative education project pointed out the importance of cooperation between various organisations, such as academic, pharmaceutical and student, in the field of education of future health professionals.
\end{abstract}

UDC Classification: 614.2, DOI: https://doi.org/10.12955/pmp.v2.186

Keywords: pharmacy students, Advanced Training in Pharmacy Care educational project, innovative education

\section{Introduction}

Pharmacists are considered the some of the most accessible healthcare professionals, among healthcare experts. In present times, the role of pharmacists has extended beyond the traditional role of dispensing medications to also provisioning of patient counselling on lifestyle modifications, medication therapy management, disease state management, and ensuring optimal medication adherence (Elnaem, 2020). This trend of change demonstrates a beneficial effect on patients' therapeutic and safety outcomes for various diseases and conditions, including diabetes mellitus, obesity, chronic obstructive pulmonary disease, psychiatric diseases, and others (Tan, 2014). The necessary reorientation of pharmacy care is confirmed, where the pharmacist's goal as a healthcare provider is to optimise the patient's treatment and improve his/her health outcomes. Despite the new trend, the dispensing of prescription and non-prescription medicines (OTC, over-the-counter) remains the main priority for most pharmacists (Mináriková, 2019).

\section{Innovative education project}

Although compulsory pharmacy practice forms part of the pharmaceutical study plan, it cannot be expected to address this need. It is therefore natural to look for other optimal, innovative, and effective ways of educating pharmacy students, an example of which is the original Advanced Training in Pharmacy Care (ATIP) educational project. It was first launched at the Faculty of Pharmacy of the Comenius University in Bratislava in the academic year 2015/2016 and five complete years of the project have already taken place in cooperation with Wörwag Pharma GmbH \& Co. KG and the Slovak Association of Pharmacy Students (Mináriková, 2017). The main objective of the project was to link the knowledge gained by the study with practice and improve students' dispensing skills, while at the same time expanding and supplementing the traditional form of education, and practical experience of students starting in the pharmacy profession. It is a complementary educational activity intended for students in their fourth year of their five-year master's degree study program, which does not interfere in any way with the compulsory curriculum (Mináriková, 2020). The project is divided into two basic phases - the spring and autumn phases and each year is devoted to a selected topic (Table 1). The spring phase of the project focuses on the professional and communication aspects of

\footnotetext{
${ }^{1}$ Comenius University, Faculty of Pharmacy, Department of Organisation and Management of Pharmacy, pagacova34@uniba.sk

${ }^{2}$ Comenius University, Faculty of Pharmacy, Department of Organisation and Management of Pharmacy, minarikova@fpharm.uniba.sk
} 
dispensation and counselling of selected medical problems, while during the autumn phase, when students are undergoing compulsory pharmacy practice, they also perform special tasks related to the topic of the given year of the project. For efficiency and benefit, it is important that the students complete both phases of the project in order to practice the correct dispensing procedure and counselling in model situations as well as in practice (Mináriková, 2017).

\begin{tabular}{|l|l|}
\hline \multicolumn{2}{|c|}{ Table 1: Themes of individual years of the innovative education project ATIP } \\
\hline Year of ATIP project & Theme of ATIP project \\
\hline $\mathbf{2 0 1 5 / 2 0 1 6}$ & Common cold and self-medication \\
\hline $\mathbf{2 0 1 6 / 2 0 1 7}$ & Back pain and high-dose vitamins of B group \\
\hline $\mathbf{2 0 1 7 / 2 0 1 8}$ & Magnesium in pharmacy practice \\
\hline $\mathbf{2 0 1 8 / 2 0 1 9}$ & Pharmacist and diabetic patient - Prevention of diabetic foot \\
\hline $\mathbf{2 0 1 9 / 2 0 2 0}$ & Upper respiratory tract infections and pharmaceutical care \\
\hline Source: Authors & \\
\hline
\end{tabular}

\section{Methods}

Data for this assessment were collected over a 5-year period. All participating students were asked to complete the self-administered questionnaire in electronic form after completing a given year of the educational project. The items of the questionnaire were divided into 3 sections, namely students' opinion on the ATIP educational project, the educational process at the Faculty of Pharmacy, and barriers in dispensation and counselling based on personal experience gained during the compulsory practice. Evaluation of consent or disapproval was measured using a 5-step Likert scale, where 1complete agreement, 2-partial agreement, 3-neither agreement, nor disagreement, 4-partial disagreement, and 5-complete disagreement. All collected data has been processed and evaluated quantitatively in the Microsoft Excel program.

\section{Results}

A total of 352 students were enrolled in five years of the ATIP educational project, but feedback for the development of our assessment was received from only 296 students. Eighty-nine percent of participating students were women and $11 \%$ were men. Every student had the opportunity to participate in the project, regardless of study results or other extracurricular activities. Most were students whose grade average was 2 . The majority (55\%) of students confirmed having a part-time job while studying. The desire to work in the community pharmacy after school was reported by 58\% of students. We also asked students if they were interested in a similar educational activity carried out by the faculty or participated in some during their studies. Participation in extracurricular activity was confirmed by $56 \%$ of students, which shows increased interest in improving knowledge and skills by students. Students' survey responses are presented in Table 2.

\begin{tabular}{|c|c|c|c|}
\hline & & \begin{tabular}{|l|} 
Number \\
\end{tabular} & Percentage (\%) \\
\hline \multirow[t]{2}{*}{ Gender } & Men & 33 & 11.15 \\
\hline & Women & 263 & 88.85 \\
\hline \multicolumn{2}{|l|}{ Average age } & 23.23 & \\
\hline \multicolumn{2}{|l|}{ Grade average } & 2 & \\
\hline \multirow[t]{2}{*}{ Working part-time job while studying } & Yes & 163 & 55.07 \\
\hline & No & 133 & 44.93 \\
\hline \multirow{3}{*}{$\begin{array}{l}\text { Interest in working in a community } \\
\text { pharmacy }\end{array}$} & Yes & 172 & 58.11 \\
\hline & No & 66 & 22.30 \\
\hline & I do not know & 58 & 19.59 \\
\hline \multirow{2}{*}{ Another educational project } & Yes & 135 & 56.25 \\
\hline & No & 105 & 43.75 \\
\hline
\end{tabular}

The ATIP educational project has been characterized by students as very well communicated, reasonably demanding, and mastered at a high professional level. The evaluation showed that it was an interesting enrichment of the compulsory curriculum, which also confirmed positive responses to improvement in dispensation and counselling skills. In the case of readiness for the profession of being a pharmacist, participation in the educational project has made a significant contribution, as confirmed by the students' responses. The results are presented in Table 3. 


\begin{tabular}{|c|c|c|c|c|c|c|}
\hline "The ATIP project ..." & ATIP 1 & ATIP 2 & ATIP 3 & ATIP 4 & ATIP 5 & Total \\
\hline ... was interesting? & 1.47 & 1.40 & 1.24 & 1.16 & 1.05 & 1.26 \\
\hline $\begin{array}{l}\text {... was of a high professional } \\
\text { standard? }\end{array}$ & 1.33 & 1.51 & 1.16 & 1.22 & 1.09 & 1.26 \\
\hline $\begin{array}{l}\text {... was reasonably demanding to } \\
\text { implement? }\end{array}$ & 1.98 & 1.79 & 1.62 & 1.78 & 1.68 & 1.77 \\
\hline $\begin{array}{l}\text {... has improved the dispensing } \\
\text { and counselling skills of the } \\
\text { pharmacy student? }\end{array}$ & 1.88 & 1.95 & 1.57 & 1.53 & 1.34 & 1.65 \\
\hline $\begin{array}{l}\text {... has been sufficiently } \\
\text { communicated? }\end{array}$ & 1.25 & 1.42 & 1.28 & 1.23 & 1.14 & 1.26 \\
\hline $\begin{array}{l}\text {... can be recommended to } \\
\text { classmates? }\end{array}$ & 1.67 & 1.30 & 1.15 & 1.09 & 1.02 & 1.25 \\
\hline $\begin{array}{l}\text {... contributed to the student's } \\
\text { readiness for the profession of } \\
\text { pharmacist? }\end{array}$ & 2.24 & 2.09 & 1.78 & 1.98 & 1.32 & 1.88 \\
\hline
\end{tabular}

We can conclude that the project represented a pleasant enrichment of the educational process when the majority of students agreed on the question of whether the study should offer similar educational activities. In assessing the students' readiness for their future profession of being a pharmacist, students were critical of the sufficiency of the study, but in the case of compulsory practice, the benefits of perceptions were more positive. Students' assessment responses are demonstrated in Table 4.

Table 4: Evaluation of the educational process at the Faculty of Pharmacy by the participating
students (N=296)
\begin{tabular}{|l|l|l|l|l|l|l|}
\hline \multicolumn{1}{|c|}{ Questions } & ATIP 1 & ATIP 2 & ATIP 3 & ATIP 4 & ATIP 5 & Total \\
\hline $\begin{array}{l}\text { Should the study offer similar } \\
\text { education projects? }\end{array}$ & 1.39 & 1.09 & 1.01 & 1.06 & 1.02 & 1.11 \\
\hline $\begin{array}{l}\text { Will the study at the faculty } \\
\text { prepare students sufficiently for } \\
\text { the profession of pharmacist? }\end{array}$ & 3.06 & 3.35 & 3.25 & 3.28 & 2.63 & 3.11 \\
\hline $\begin{array}{l}\text { Will the completion of } \\
\text { compulsory pharmacy practice } \\
\text { prepare a student enough for } \\
\text { the profession of pharmacist? }\end{array}$ & 2.12 & 2.14 & 1.91 & 2.02 & 1.84 & 2.00 \\
\hline
\end{tabular}
$\begin{aligned} & \text { *A lower score indicates a higher consent rate. } \\
& \text { Source: Authors }\end{aligned}$

Analysis of students' responses regarding obstacles to dispensation and counselling suggested that they saw a lack of practical experience (1.34) as the biggest obstacle. The given obstacle could be improved by involving interactive and innovative forms (dispensing trainer, presentation techniques, etc.) in teaching processes. This was followed obstacles such as a lack of time to devote to patients and their problems (1.84) and requirements that differ from the knowledge acquired during the study (1.87). Dispensations and counselling include conversation and interaction between pharmacist and patient, but in the students' responses obstacles such as a lack of privacy or lack of care were not among the most important. A neutral stance was taken on obstacles such as lack of theoretical knowledge, insufficient ability to communicate with the patient, also a lack of appropriate software and databases and lack of personal motivation. Insufficient support from other pharmacy staff (3.98) was perceived by students as the obstacle which least affects the quality of dispensation and counselling. Students' responses are presented in Table 5. 


\begin{tabular}{|c|c|c|c|c|c|c|}
\hline Obstacles & ATIP 1 & ATIP 2 & ATIP 3 & ATIP 4 & ATIP 5 & Total \\
\hline Lack of practical experience & 1.37 & 1.32 & 1.24 & 1.47 & 1.30 & 1.34 \\
\hline Lack of theoretical knowledge & 2.80 & 2.81 & 2.76 & 2.72 & 2.84 & 2.79 \\
\hline $\begin{array}{l}\text { Patient requirements are } \\
\text { different from what a student } \\
\text { prepares for during studies }\end{array}$ & 1.92 & 1.77 & 1.85 & 1.87 & 1.93 & 1.87 \\
\hline $\begin{array}{l}\text { Insufficient ability to } \\
\text { communicate with the patient }\end{array}$ & 2.59 & 2.46 & 2.49 & 2.58 & 2.71 & 2.57 \\
\hline $\begin{array}{l}\text { Lack of time to devote to the } \\
\text { individual patient }\end{array}$ & 1.82 & 1.81 & 2.01 & 1.69 & 1.89 & 1.84 \\
\hline $\begin{array}{l}\text { Lack of privacy to talk to a } \\
\text { patient }\end{array}$ & 2.33 & 2.07 & 2.40 & 2.13 & 2.21 & 2.23 \\
\hline $\begin{array}{l}\text { Patient's disinterest to consult } \\
\text { with a pharmacist }\end{array}$ & 2.45 & 2.58 & 2.44 & 2.09 & 2.20 & 2.35 \\
\hline $\begin{array}{l}\text { Lack of appropriate software } \\
\text { and databases with expert } \\
\text { information that could be } \\
\text { directly used during patient } \\
\text { counselling }\end{array}$ & 3.45 & 2.84 & 4.50 & 2.89 & 3.13 & 3.36 \\
\hline $\begin{array}{l}\text { Insufficient support from other } \\
\text { pharmacy staff }\end{array}$ & 3.53 & 3.61 & 4.22 & 4.06 & 4.50 & 3.98 \\
\hline $\begin{array}{l}\text { Pressure to sell products } \\
\text { according to pharmacy needs, } \\
\text { not with respect to the patient }\end{array}$ & 2.82 & 3.07 & 3.56 & 3.44 & 3.04 & 3.19 \\
\hline $\begin{array}{l}\text { Lack of personal motivation to } \\
\text { provide dispensation and } \\
\text { counselling professionally and } \\
\text { for the benefit of the patient }\end{array}$ & 3.49 & 3.47 & 3.78 & 3.45 & 3.63 & 3.56 \\
\hline
\end{tabular}

\section{Discussion}

The pharmacy profession faces a future with new models of care as well as expanded access to patient data and constantly evolving technology. That is why students sought project opportunities outside the compulsory curriculum based on their interest and educational needs (Patel, 2017). Proper dispensation and counselling skills are important for effective patient care as they can shed light on misunderstandings, prevent misuse of medicines, while also helping to reduce financial costs and increase benefits for patients. Students can provide invaluable insight on what is working well and can give constructive feedback to teachers for improving the compulsory curriculum (Svensberg, 2018). The curriculum must foster innovative strategies that enable students a transition from dependent to active, self-directed, lifelong learners in providing patient-centred care and promoting health improvement (Wongwiwatthananukit, 2013). Thus, moving forward, we must recognize that implementing active-learning strategies may be a valid way to address the increasing knowledge base by facilitating the training of pharmacy graduates who can find, process, analyse, and apply new information with their patients (Stewart, 2011). The results of the assessment affirm that the inclusion of simulation approaches, such as dispensation training, are useful educational tools in the changing environment of pharmaceutical education.

\section{Conclusion}

Innovation in contemporary education has become an inevitable developmental trend and plays a fundamental role in shaping future pharmacists. As confirmed the innovative educational project, students perceive education at the Faculty of Pharmacy of the Comenius University in Bratislava much more comprehensively than just completing a compulsory curriculum. We must not forget that the study seeks to respond to current trends in the field of health care but there are limits that need to be maintained. 


\section{References}

Elnaem, M. H., Rosley, N. F. F., Alhifany, A. A., Elrggal, M. E., \& Cheema, E. (2020). Impact of Pharmacist-Led Interventions on Medication Adherence and Clinical Outcomes in Patients with Hypertension and Hyperlipidemia: A Scoping Review of Published Literature Journal of Multidisciplinary Healthcare, Volume 13, 635-645. https://doi.org/10.2147/jmdh.s257273

Mináriková, D. (2017). Môžeme inovovat’ vzdelávanie študentov farmácie?. Súčasná klinická prax, 2, 30-35.

Mináriková, D. (2020). Ako sú pripravené lekárne na kardiovaskulárnu prevenciu - čo ukázal projekt ATIP. Súčasná klinická prax, 1, 40-44.

Mináriková, D., Fazekaš, T. š., \& Stanko, P. (2019). Mystery shopping and education of pharmacy students in dispensing and counselling about OTC medicine. Klinická Farmakologie a Farmacie, 33(2), 4-10. https://doi.org/10.36290/far.2019.008

Patel, R. M. (2017). The Innovation Opportunity in Pharmacy Education Standards. INNOVATIONS in Pharmacy, 8(3), 8. https://doi.org/10.24926/iip.v8i3.533

Svensberg, K., Sporrong, S. K., Lupattelli, A., Olsson, E., Wallman, A., \& Björnsdottir, I. (2018). Nordic Pharmacy Students' Opinions of their Patient Communication Skills Training. American Journal of Pharmaceutical Education, 82(2), 6208. https://doi.org/10.5688/ajpe6208

Tan, E. C. K., Stewart, K., Elliott, R. A., \& George, J. (2014). Pharmacist services provided in general practice clinics: A systematic review and meta-analysis. Research in Social and Administrative Pharmacy, 10(4), 608-622. https://doi.org/10.1016/j.sapharm.2013.08.006

Wongwiwatthananukit, S., Zeszotarski, P., Thai, A., Fuller, R. A., Owusu, Y., Tan, C., Gomez, L., \& Holuby, S. (2013). A Training Program for Pharmacy Students on Providing Diabetes Care. American Journal of Pharmaceutical Education, 77(7), 153. https://doi.org/10.5688/ajpe777153 